\title{
GAMBARAN PEMAHAMAN TEORI PSIKOANALISIS DAN IMPLIKASINYA DALAM PENDIDIKAN PADA MATA KULIAH KARAKTERISTIK DAN KOMPETENSI USIA DEWASA PADA MAHASISWA BIMBINGAN DAN KONSELING FKIP UNTIRTA
}

\author{
Putri Dian Dia Conia ${ }^{*}$, Meitami Sofiyanti ${ }^{2}$. \\ ${ }^{12}$ Universitas Sultan Ageng Tirtayasa \\ putriconia@untirta.ac.id
}

\begin{abstract}
ABSTRAK
Salah satu materi yang penting untuk dipelajari oleh mahasiswa bimbingan dan konseling dalam mata kuliah Karakteristik dan Kompetensi Usia Dewasa adalah mengenai pemahaman teori kepribadian pada usia dewasa. Salah satu tokoh teori kepribadian yaitu Sigmund Freud merupakan penggagas teori Psikoanalisis, yang merupakan teori yang berusaha untuk menjelaskan tentang hakikat dan perkembangan kepribadian manusia. Mahasiswa yang sudah masuk dalam kategori usia dewasa awal yaitu usia 18 tahun keatas, juga dapat lebih memahami mengenai kepribadian masing-masing dengan mempelajari mengenai teori kepribadian lebih mendalam. Teori kepribadian yang diungkapkan oleh Sigmund Freud juga wajib untuk dipelajari oleh mahasiswa karena memberikan implikasi terhadap bidang Pendidikan. Berdasarkan hal tersebut maka penting bagi mahasiswa yang mengampu mata kuliah Karakteristik dan Kompetensi Usia Dewasa untuk mengetahui lebih jelas mengenai gambaran pemahaman kepribadian berdasarkan teori Psikoanalisis dari Sigmund Freud. Metode penelitian yang digunakan adalah deskriptif kuantitatif dengan instrumen non-tes yaitu wawancara. Wawancara dilakukan kepada 5 mahasiswa semester 3 jurusan bimbingan dan konseling FKIP Universitas Sultan Ageng Tirtayasa.
\end{abstract}

Kata kunci : psikoanalisis, perkembangan kepribadian, pendidikan.

\begin{abstract}
One of the important materials for guidance and counseling students to learn in the Adult Age Characteristics and Competencies course is the understanding of personality theory in adulthood. One of the personality theory figures, Sigmund Freud, is the initiator of the Psychoanalytic theory, which is a theory that seeks to explain the nature and development of the human personality. Students who are already in the early adult age category, namely the age of 18 years and over, can also understand more about each other's personality by studying personality theory more deeply. The personality theory expressed by Sigmund Freud is also mandatory for students to study because it has implications for the field of education. Based on this, it is important for students who teach the Characteristics and Competencies of Adult Age courses to know more clearly about the description of personality understanding based on the Psychoanalytic theory of Sigmund Freud. The research method used is descriptive quantitative with a non-test instrument, namely interviews. Interviews were conducted with 5 students at 3rd semester majoring in Guidance and Counseling FKIP Sultan Ageng Tirtayasa University. Keywords: psychoanalytic, personality development, education
\end{abstract}

\section{PENDAHULUAN}

Personality adalah arti dari kepribadian dalam bahasa Inggris, sedangkan akar kata kepribadian itu sendiri yaitu berasal dari bahasa latin yaitu persona. Persona berarti topeng, 
Prosiding The 1st National Conference on Applied Business, Education, \& Technology (NCABET)"

Unversitas Bina Bangsa 2021

DOI Article : 10.46306/ncabet.v1i1.43

yang dapat diartikan sebagai topeng yang dipakai oleh manusia (Rosyidi, 2010). Kepribadian menurut psikologi merupakan suatu organisasi yang dinamis dari sistem psikofisik individu yang menentukan tingkah laku dan pemikirian yang khas dari individu tersebut (Koeswara, 1991). Kepribadian juga merupakan suatu bidang studi empiris, dan bukan sebagai dasar untuk melakukan penilaian baik-buruk suatu perilaku. Namun kepribadian juga memiliki ruang lingkup dan batasan - batasan tertentu, misalnya adalah pentingnya melihat kepribadian dari sudut "sejarah hidup" seorang individu. Teori psikoanalisis yang dikemukakan oleh Sigmund Freud merupakan teori yang berusaha untuk menjelaskan hakikat manusia dan juga perkembangan kepribadian manusia. Terdapat beberapa hal yang diutamakan dalam teori psikoanalisis, yaitu mengenai emosi, motivasi, dan aspek - aspek internal lainnya. Teori psikoanalitis mengasumsikan bahwa perkembangan manusia berlangsung secara tidak disadari (unconscious) dan diwarnai oleh emosi, yang pada umumnya terjadi pada masa awal kehidupan manusia (Olson dan Hergenhahn, 2011). Pemahaman Freud tentang kepribadian manusia didasarkan pada pengalaman - pengalaman dengan pasiennya, analisis mengenai mimpi yang dialaminya, dan sumber bacaannya yang luas tentang beragam ilmu pengetahuan dan perilaku manusia. Pengalaman yang dilaluinya, menjadi dasar baginya dalam mengemukakan teorinya. Pada saat psikologi tengah memprioritaskan penelitian atas kesadaran dan memandang kesadaran (conscious) sebagai aspek utama dari kehidupan mental, Freud mengemukakan bahwa kesadaran hanyalah bagian kecil saja dari kehidupan mental, sedangkan bagian yang terbesarnya adalah mengenai ketidaksadaran (unconscious) atau alam tak sadar (Suryabrata, 2002).

Freud mengibaratkan kesadaran dan ketidaksadaran itu menjadi sebuah gunung es yang terapung dimana bagian yang muncul ke permukaan air (kesadaran / conscious) jauh lebih kecil daripada bagian yang tenggelam (ketidaksadaran / unconscious) (Olson dan Hergenhahn, 2011). Sedangkan menurut Sigmund Freud, kepribadian memiliki tiga kedalaman yang teritegrasi dari id (dorongan biologis), ego (mekanisme pengontrol dan mengendalikan id), dan super ego (pengontrol dalam kepribadian melalui norma sosial). Menurut Freud elemen id merupakan elemen yang unconscious, selalu berorientasi pada kesenangan, dan juga menuntut pemuasan kebutuhan secara langsung. Id memiliki dua cara untuk memuskan kebutuhan dengan tidakan reflek atau pemenuhan keinginan. Sedangkan elemen ego merupakan mekanisme pengontrol dan berorientasi pada realitas, selain itu ego juga merupakan elemen mediasi antara superego, id, dan tuntutan realitas. Ego hadir untuk mengendalikan id dan dan membuat manusia menjalin kontak dengan pengalaman - pengalaman yang dapat memuaskan kebutuhan tubuh. Elemen terakhir adalah superego, yang dibentuk dari sikap - sikap moral 
Prosiding The 1st National Conference on Applied Business, Education, \& Technology (NCABET)"

Unversitas Bina Bangsa 2021

DOI Article : 10.46306/ncabet.v1i1.43

orangtua dan norma sosial yang dipelajari ditahun - tahun pertama kehidupan manusia, yang pada akhirnya akan membentuk prinsip - prinsip moral dalam diri manusia tersebut. Dari ketiga elemen kepribadian tersebut, tugas elemen ego lah yang paling berat, karena harus mengendalikan orientasi realitas sehingga dibutuhkan mekanisme - mekanisme pertahanan ego. Mekanisme pertahanan ego merupakan strategi yang digunakan oleh individu untuk menghalau dorongan id maupun untuk menghadapi tekanan dari superego dan terhadap ego, dengan tujuan untuk mengurangi atau meredakan kecemasan yang dialami individu terhadap dorongan atau tekanan tersebut (Alwisol, 2005).

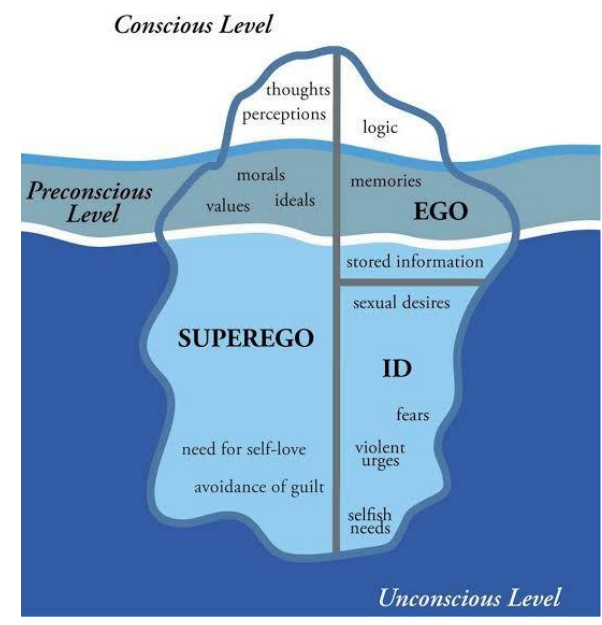

Gambar 1. Gunung Es Sigmund Freud (Source: Google)

Mekanisme pertahanan ego menurut Freud diantaranya adalah represi, sublimasi, proyeksi, displacement, rasionalisasi, pembentukan reaksi, dan regresi (Alwisol, 2005). Berikut merupakan 7 mekanisme pertahanan ego yang diungkapkan oleh Freud yang umum dijumpai pada setiap individu (Koeswara, 2001) :

1. Represi, yaitu mekanisme yang dilakukan oleh ego untuk meredakan kecemasan dengan cara menekan dorongan-dorongan yang menjadi penyebab kecemasan tersebut ke dalam ketidaksadaran.

2. Sublimasi, merupakan mekanisme pertahanan ego yang ditujukan untuk mencegah atau meredakan kecemasan dengan cara mengubah dan menyesuaikan dorongan $i d$, yang menjadi penyebab kecemasan ke dalam bentuk tingkah laku yang bisa diterima, dan bahkan dihargai oleh masyarakat.

3. Proyeksi, merupakan mekanisme pertahanan ego dengan merepresi kebenaran tentang diri yang akan membangkitkan kecemasan sehingga memilih untuk menganggap orang lain yang memiliki kebenaran dirinya, atau berdalih menutupi kesalahan dengan menyalahkan lingkungan/situasi hidup sebagai penyebabnya. 
4. Displacement, adalah pengungkapan dorongan yang menimbulkan kecemasan kepada objek atau individu yang kurang berbahaya dibanding individu semula. Mekanisme ini dilakukan dengan mengganti pemuas kebutuhan dengan pemuas kebutuhan lain.

5. Rasionalisasi, menunjuk kepada upaya individu memutarbalikkan kenyataan, dalam hal ini kenyataan yang mengancam ego, melalui dalih tertentu yang seakan-akan masuk akal.

6. Pembentukan reaksi, merupakan upaya mengatasi kecemasan karena insdividu memiliki dorongan yang bertentangan dengan norma, dengan cara berbuat sebaliknya.

7. Regresi, sebuah upaya mengatasi kecemasan dengan bertinkah laku yang tidak sesuai dengan tingkat perkembangannya.

Selain elemen-elemen kepribadian yang dibahas dalam teori psikoanlisis, Freud juga mengungkapkan mengenai insting yang juga merupakan sentral dalam pendekatannya. Menurut Freud insting merupakan perwujudan psikologis dari sumber rangsangan atau dorongan yang dibawa oleh manusia sejak lahir. Freud juga membahas mengenai kecemasan yang dapat dialami oleh setiap individu. Menurut Freud kecemasan adalah perasaan - perasaan yang tidak menyenangkan yang disertai dengan adanya sensasi tubuh yang memberikan tanda pada seseorang akan adanya bahaya. Hal tersebut berkaitan dengan pembahasan mengenai mekanisme pertahanan ego yang memiliki manfaat besar dalam mengalau kecemasan (Budiraharjo, 1997).

Hubungan antara psikoanalisis dengan pendidikan sangatlah kompleks, yang berarti bahwa psikoanalisis telah mengalami banyak perkembangan dan memperkaya tingkat perilaku (sikap) dalam ukuran hubungan pendidikan (hubungan antara pendidik, orangtua, peserta didik yang bersangkutan). Maka dalam hal ini teori psikoanalisis menyumbang berbagai pikiran dalam perkembangan dunia pendidikan. Pendidikan berdasarkan teori psikoanalisis memiliki pengertian yang cukup luas, terhadap berbagai tindakan yang dilakukan oleh orang dewasa, ahli, atau non-pakar, guru dan orangtua, untuk membentuk dan memengaruhi perilaku peserta didik yang sedang berada pada tahap berkembang sesuai dengan pemikiran idealis mereka. Maka tujuan yang dinyatakan berdasarkan analisis psikoanalisis adalah memberi tuntunan bagi pendidik dan peserta didik tentang pemahaman perkembangan kepribadian yang berkaitan dengan perilaku dan kemajuan yang dicapai peserta didik. Peserta didik dalam prosesnya akan selalu berkaitan dengan proses belajar yang dialami peserta didik, baik ketika berada di sekolah maupun lingkungan rumah atau keluarganya sendiri. Oleh karenanya, pemahaman yang benar mengenai arti belajar dengan segala aspek, bentuk, dan manifestasinya mutlak diperlukan oleh para pendidik khususnya para guru. Kekeliruan atau ketidaklengkapan persepsi mereka 
Prosiding The 1st National Conference on Applied Business, Education, \& Technology (NCABET)"

Unversitas Bina Bangsa 2021

DOI Article : 10.46306/ncabet.v1i1.43

terhadap proses belajar dan hal-hal yang berkaitan mungkin akan mengakibatkan kurang bermutunya hasil pembelajaran yang dicapai peserta didik (Syah, 2010).

Berdasarkan perkembangannya teori psikoanalisis cukup banyak dapat diimplementasikan dalam dunia pendidikan. Beberapa diantaranya yang berkaitan dengan konsep kecemasan yang dikemukakan oleh Freud berkaitan dengan proses pendidikan. Kecemasan merupakan fungsi ego untuk memperingatkan individu tentang kemungkinan suatu bahaya sehingga individu dapat menyiapkan reaksi adaptif yang sesuai (Olson dan Hergenhahn, 2011). Pada ranah pendidikan, konsep kecemasan pada tiap individu dapat diolah dan dikembangkan oleh para pengajar demi kebaikan peserta didik. Peserta didikpun dibantu untuk lebih mampu menghargai diri dan oran lain serta lingkungannya. Oleh karena itu konsep kecemasan diarahkan ke pendidikan ranah afektif atau karakternya. Implementasi lainnya dari teori psikoanalisis pada proses pendidikan yaitu mengenai kecerdasan majemuk. Setiap individu memiliki kecerdasan yang berbeda-beda, kecerdasan tidaklah berpatokan pada angka yang dihasilkan pada $I Q$ atau Intelligence Quotients. Pendidikan pada dasarnya harus mampu menjadi penghubung kecerdasan yang dimiliki oleh peserta didik, misalnya dengan mengembangkan bakat dan minat sesuai dengan kebutuhan peserta didik. Pernyataan tersebut sesuai dengan teori Freud yang menyebut bahwa manusia sebagai makhluk yang memiliki keinginan dan kebutuhan dasar. Implementasi lainnya adalah pendidik harus mampu mengontrol dan mengatur sikap peserta didik agar terarah menjadi lebih positif. Hal tersebut dapat dilakukan dengan membantu peserta didik dengan lebih memahami perkembangan kepribadiaanya.

Berdasarkan penjelasan diatas, kami melihat bahwa pemahaman mengenai teori psikoanalisis untuk mahasiswa bimbingan dan konseling sangatlah penting. Pemahaman berkembang semakin dalam dan kuat apabila diuji oleh berbagai macam pengalaman baru (Trianto, 2009). Pembelajaran pada dasarnya merupakan proses penambahan informasi dan kemampuan baru (Sanjaya, 2009). Maka dengan adanya penjelasan dari dosen mengenai teori Psikoanalisis, dapat membantu peserta didik untuk mengimplementasikan kedalam diri peserta didik berkaitan dengan proses belajar dan perkembangan kepribadiannya ataupun perilakunya.

\section{METODE PENELITIAN}

Subjek penelitian ini adalah lima mahasiswa putri dari jurusan bimbingan dan konseling, Universitas Sultan Ageng Tirtayasa angkatan 2020 yang mengampu mata kuliah karakteristik dan kompetensi usia dewasa serta sedang mempelajari mengenai teori psikoanalisis. Kemudian untuk mendapatkan pernyataan mengenai pemahaman teori psikoanalisis dari kelima 
Prosiding The 1st National Conference on Applied Business, Education, \& Technology (NCABET)"

Unversitas Bina Bangsa 2021

DOI Article : 10.46306/ncabet.v1i1.43

mahasiswa, peneliti menggunakan instrumen non tes berupa wawancara serta dalam mengolah data hasil wawancara peneliti menggunakan metode deskriptif kualitatif. Maksud dari deskriptif yaitu mengumpulkan data berdasarkan faktor-faktor yang menjadi pendukung terhadap objek penelitian, kemudian menganalisa faktor-faktor tersebut untuk dicari peranannya (Arikunto, 2010). Sedangkan kualitatif merupakan penelitian yang berhubungan dengan ide, persepsi, pendapat, kepercayaan orang yang akan diteliti dan kesemuanya tidak dapat diukur dengan angka (Prabowo \& Heriyanto, 2013). Melalui wawancara pasca dilaksanakan perkuliahan, diharapkan peneliti dapat mengetahui gambaran pemahaman mahasiswa mengenai teori psikoanalisis dan implikasinya dalam pendidikan, apakah mahasiswa memahami materi mengenai elemen - elemen kepribadian, serta perkembangan kepribadian dari mahasiswa itu sendiri, dan apakah teori psikoanalisis dapat di implementasikan kedalam proses belajar.

Pada penelitian ini, teori yang digunakan dalam penelitian tidak dipaksakan untuk memperoleh gambaran seutuhnya mengenai suatu hal menurut pandangan manusia yang telah diteliti (Sulistyo, 2006). Maka metode pendekatan deskriptif kualitatif adalah metode pengolahan data dengan cara menganalisa faktor-faktor yang berkaitan dengan objek penelitian dengan penyajian data secara lebih mendalam terhadap objek penelitian.

\section{HASIL DAN PEMBAHASAN}

Berdasarkan hasil wawancara pada kelima mahasiswa dari jurusan bimbingan dan konseling, Universitas Sultan Ageng Tirtayasa angkatan 2020 yang mengampu mata kuliah karakteristik dan kompetensi usia dewasa, didapatkan hasil bahwa dengan penjelasan mengenai teori psikoanalisis mahasiswa dapat mengetahui pengertian dari kepribadian secara lebih spesifik. Maksud dari lebih spesifik yaitu mahasiswa menjadi lebih mengetahui bahwa kepribadian erat kaitannya dengan pendidikan ataupun perilaku dari pendidik dan peserta didik. Mahasiswa juga mengatakan bahwa mereka mendapatkan pengetahuan yang baru bahwa emosi dan motivasi juga merupakan bagian dari teori psikoanalisis. Emosi dan motivasi juga terkait dengan elemen - elemen kepribadian yang diungkapkan oleh Freud. Mahasiswa memahami bahwa setiap individu memiliki tiga elemen kedalaman dalam kepribadiannya yaitu $i d$, ego, dan superego.

Ketika ditanya mengenai pemahaman mahasiwa mengenai elemen $i d$, mahasiswa lebih mudah memahami materi tersebut ketika diberikan contoh - contoh yang konkret. Misalnya salah satu contoh dari cara individu dalam melakukan pemenuhan kebutuhan $i d$ adalah dengan Tindakan reflek, misalnya ketika seseorang bersin, itu merupakan tindakan reflek karena adanya ketidaknyamanan yang dirasakan dihidung dan Tindakan relfek tersebut merupakan 
Prosiding The 1st National Conference on Applied Business, Education, \& Technology (NCABET)"

Unversitas Bina Bangsa 2021

DOI Article : 10.46306/ncabet.v1i1.43

bagian dari pemenuhan kebutuhan $i d$. Ketika ditanyakan mengenai elemen ego dan superego, mahasiswa pun lebih memahami Ketika diberikan contoh yang konkret yang terjadi di keseharian. Misalnya saat dijelaskan bahwa pada saat seseorang sedang merasakan lapar, maka id akan memberikan sinyal atau dorongan (impuls) pada ego mengenai keinginan tersebut, ego tidak lagi melakukan pengetesan realitas namun saat keinginan untuk makan muncul maka ego akan mewujudkan keinginan tersebut dengan berorientasi pada realitas yaitu langsung menyediakan objek makanan yang dikirimkan melalui bayangan - bayangan yang diberikan oleh $i d$. Tetapi jika seseorang tumbuh dengan norma - norma sosial yang baik maka superego akan dapat membantu ego untuk memberitahukan bahwa terdapat prinsip - prinsip social yang harus dipegang teguh agar tidak menimbulkan kecemasan. Oleh karena itu superego dapat mengirimkan sinyal pada ego agar dapat mengahalau dorongan ataupun tekanan agar sesuai dengan situasi lingkungan dan tidak langsung berorientasi pada realitas atau pemenuhan langsung keinginan. Mahasiswa mengatakan Ketika proses pemberian materi banyak menggunakan contoh konkret dalam kehidupan sehari - hari, maka mereka lebih mudah untuk mencerna materi tersebut.

Berkaitan dengan elemen kepribadian id, ego, dan superego, mahasiswa mengungkapkan bahwa mereka menyadari betapa pentingnya memahami norma sosial yang harus diterpakan dalam kehidupan sehari-hari. Selain itu mahasiswa juga mengatakan bahwa mereka juga mendapatkan pengetahuan tambahan mengenai mekanisme - mekanisme pertahanan ego, yang dapat membantu mereka untuk mengatasi kecemasan yang mungkin saja dialami dalam proses belajar. Misalnya kecemasan ketika akan presentasi, ujian, atau saat menjawab langsung pertanyaan dari dosen. Kecemasan merupakan fungsi ego untuk memperingatkan individu tentang kemungkinan suatu bahaya sehingga individu dapat menyiapkan reaksi adaptif yang sesuai. Pada ranah pendidikan, konsep kecemasan pada tiap individu dapat diolah dan dikembangkan oleh para pengajar demi kebaikan peserta didik. Peserta didikpun dibantu untuk lebih mampu menghargai diri dan oran lain serta lingkungannya. Oleh karena itu konsep kecemasan diarahkan ke pendidikan ranah afektif atau karakternya.

Pada bagian lainnya mahasiswa juga merasa lebih memahami mengenai perkembangan kepribadian, terkait dengan teori psikoanalisis yang menyatakan bahwa perkembangan manusia manusia berlangsung secara tidak disadari (unconscious) dan diwarnai oleh emosi, yang pada umumnya terjadi pada masa awal kehidupan manusia (Olson dan Hergenhahn, 2011). Dengan memberikan contoh konret dari setiap mekanisme pertahanan ego, mahasiswa mengatakan bahwa contoh - contoh yang diberikan dapat membantu untuk lebih mampu dalam menghadapi kecemasan yang timbul ketika menghadapi kesulitan dalam proses belajar. Selain itu 
Prosiding The 1st National Conference on Applied Business, Education, \& Technology (NCABET)"

Unversitas Bina Bangsa 2021

DOI Article : 10.46306/ncabet.v1i1.43

mahasiswa juga mengatakan bahwa saat ini mereka mulai menyadari bahwa kecerdasan tidak hanya berpatokan pada angka intelengensi $(I Q)$ namun prestasi belajar dapat juga diperoleh dari bakat dan minat yang dimiliki oleh mahasiswa tersebut. Mahasiswa menjadi lebih mampu untuk menghargai diri sendiri dan lingkungannya dalam proses pembelajaran yang sedang dihadapi atau yang telah diraih. Hal ini berarti bahwa mahasiswa memahami teori Freud yang menyatakan bahwa manusia sebagai makhluk yang memiliki keinginan dan kebutuhan dasar. Dari kelima mahasiswa yang telah diwawancarai didapatkan juga fakta bahwa mereka merasa lebih antusias untuk lebih jauh belajar memahami teori kepribadian lainnya, agar dapat membantu mereka dalam memahami perkembangan diri mereka sendiri.

Adapun beberapa kekurangan dalam perkuliahan mengenai teori psikoanalisis diantaranya adalah waktu perkuliahan yang terbatas dan juga metode pembelajaran yang juga terbatas dikarenakan perkuliahan dilaksanakan melalui metode daring yang seharusnya selain dengan pemberian contoh pada setiap teori, mahasiswa seharusnya dapat praktek langsung untuk mengobservasi dan melakukan wawancara terkait kepribadian individu dilingkungan sekitar. Sehingga mahasiswa belum cukup untuk lebih dalam mempelajari teori psikoanalisis beserta dengan contoh - contoh konret lainnya yang bisa ditemukan dalam kehidupan sehari hari. Namun berdasarkan hasil wawancara juga diperoleh, bahwa materi pembelajaran mengenai teori psikoanalisis dapat membantu peserta didik untuk lebih memahami perkembangan kepribadian dirinya sendiri, dan memberikan dampak positif terhadap perilaku yang ditunjukan peserta didik pada lingkungannya. Selain itu, dalam berbagai kekurangan dan kelebihan dalam hasil wawancara, pembelajaran selanjutnya sebaiknya dapat disusun dengan lebih maksimal dalam perkuliahan sehingga dapat mencapai tujuan lain yang lebih maksimal.

\section{KESIMPULAN DAN SARAN}

Teori psikoanalisis yang dikembangkan oleh Sigmund Freud merupakan teori yang dapat diimplementasikan untuk menganalisis keadaan psikologis manusia. Menurut Freud, tingkah laku manusia justru didominasi oleh alam bawah sadar yang berisi id, ego, dan super ego. Pada ranah pendidikan, konsep psikoanalisis juga dapat diaplikasikan. Maka dari itu pendidikan juga perlu mempertimbangkan konsep-konsep psikoanalisis dalam mengembangkan dan mendidik peserta didiknya. Salah satunya dengan memperhatikan konsep dari psikoanalisis yang menyatakan bahwa manusia merupakan makhluk yang memiliki keinginan dan kebutuhan dasar. Hal lain yang juga dapat diterapkan dalam proses pendidikan adalah dengan menggunakan berbagai pendekatan dalam proses pembelajaran kepada para peserta didik. Oleh karena itu dibutuhkan suatu pendekatan secara pribadi dalam menangani peserta didik yang 
Prosiding The 1st National Conference on Applied Business, Education, \& Technology (NCABET)"

Unversitas Bina Bangsa 2021

DOI Article : $10.46306 /$ ncabet.v1i1.43

sedang dalam masa perkembangan dengan pemikiran yang idealis seusianya. Memberikan pemahaman mengenai berbagai hal yang berkaitan dengan perkembangan kepribadian, dapat membantu peserta didik untuk lebih memahami perkembangan kepribadian diri mereka sendiri. Hal tersebut dapat membantu peserta didik dalam meningkatkan pemahaman mereka juga terhadap norma sosial, yang bermanfaat untuk berperilaku yang lebih positif.

\section{UCAPAN TERIMAKASIH}

Kami mengucapkan terimakasih kepada seluruh responden yang telah bersedia untuk mengikuti tahapan penelitian. Kami juga mengucapkan terimakasih kepada pihak panitia yang telah menyelenggarakan kegiatan The 1st National Conference on Applied Business, Education, \& Technology (NCABET)" Unversitas Bina Bangsa 2021 sehingga penelitian ini dapat terlaksana.

\section{DAFTAR PUSTAKA}

Alwisol. (2005). Psikologi kepribadian. Malang: UMM Press.

Arikunto, S. (2010). Prosedur Penelitian : Suatu Pendekatan Praktik. Jakarta: Rineka Cipta. Budiharjo, Paulus. (1997). Mengenal Teori Kepribadian Mutakhir. Yogyakarta: Kanisius. Koeswara, E. (1991). Teori-teori Kepribadian. Bandung: PT Eresco.

Olson, H. W \& Hergenhahn, R. B. (2011). Theories of Personality. New York, NY: Pearson Education.

Prabowo, A., \& Heriyanto. (2013). Analisis Pemanfaatan Buku Elektronik (E-Book) oleh Pemustakaan di Perpustakaan SMA Negeri 1 Semarang. Jurnal Ilmu Perpustakaan, 2 (2),

1-9. Diambil kembali dari http://ejournal-s1.undip.ac.id/index.php/jip

Rosyidi, Hamim. (2010). Handout psikologi kepribadian I. Surabaya: IAIN Sunan Ampel Sanjaya, Wina. (2009). Strategi Pembelajaran Berorientasi Standar Proses Pendidikan. Jakarta: Kencana.

Syah, M. (2010). Psikologi Pendidikan dengan Pendekatan Baru. Bandung: Rosdakarya.

Sulistyo, B. (2006). Metode Penelitian. Jakarta: Wedatama Widya Sastra dan Fakultas Ilmu Pengetahuan Budaya Universitas Indonesia.

Sumadi Suryabrata. (2002). Psikologi kepribadian. Jakarta: PT. RajaGrafindo Persada. Trianto. (2009). Mendesain Model Pembelajaran yang Inovatif Progresif. Jakarta: Kencana. 